\title{
PROSPECT ON DESALINATION AND OTHER NON-ELECTRIC APPLICATIONS OF NUCLEAR ENERGY IN INDONESIA
}

\author{
Geni Rina Sunaryo \\ Center for Reactor Technology and Nuclear Safety \\ PTRKN-BATAN, Bldg. 80, Puspiptek Area, Serpong, Tangerang 15310, Indonesia
}

\begin{abstract}
PROSPECT ON DESALINATION AND OTHER NON-ELECTRIC APPLICATIONS OF NUCLEAR ENERGY IN INDONESIA. As the standard of living increases globally, the need for fresh water and industrial products are also increasing; they require energy for production and hence, the demand for energy-both electric and non-electric, is also increasing. This trend also happens in Indonesia as an archipelagic country. In an effort to meet the current and future water and energy demands, Indonesia is now planning to utilize nuclear power for not only electricity but also producing fresh water through desalination process named Nuclear Desalination. Feasibility and option studies have been carried out by Indonesian National Nuclear Energy Agency, locally called Badan Tenaga Nuclear Nasional or 'BATAN' since 1995, and also in collaboration with Korean Atomic Energy \& Research Institute (KAERI) since 2002. The study concluded that it would be technically feasible to build desalination plants on selected sites pending further economic assessments. BATAN also has a duty to study the future Nuclear Power Plant (NPP) that can be coupled to various industrial processes. From the literature study it seems that HTGR (High Temperature Gas Cooled Reactor) is the promising one because of its huge range steam temperature. Beside that study, BATAN also has (1) developed a small scale Mechanical Vapor Compression system to study and establish vital parameters that will affect system performance, water chemistry, corrosion, scaling, evaporation, condensation, and choice of materials and (2) basic research on hydrogen production through the Iodine Sulfur (IS) process.
\end{abstract}

Keywords : Desalination, Nuclear Power Plant (NPP), HTGR

\section{INTRODUCTION}

Indonesia is a huge archipelagic country, extending $5,120 \mathrm{~km}$ from east to west and $1,760 \mathrm{~km}$ from north to south encompassing as many as 18,000 islands of which about 6,000 are inhabited by 215 million people. Water is a central input for agricultural production. Potential water resources are rainwater, groundwater and surface water. The amount of water in Indonesia fluctuates by season and is distributed differently among the regions. Naturally, the rainfall varies significantly depending on locations and seasonal changes (wet and dry seasons). About $60 \%$ of the inhabited regions receive plenty of annual precipitations in the range of 2,000 to $3,500 \mathrm{~mm}$, whereas some areas see greater than $5,000 \mathrm{~mm}$ and some less than $1,000 \mathrm{~mm}$. In addition to these generous rainfalls, Indonesia is endowed with not less than 5,590 rivers flowing over 5,500 billion tons of water per year (or $5,500 \mathrm{~km}^{3} /$ year) [1]. 
Indonesia may appear to have an abundant supply of water and be free from water shortage problems. In reality, there are some main problems facing in Indonesia i.e. rising water demand, lack of upland/upstream land management, erosion - related degradation, population growth that affect the water pollution, inefficient irrigation water management that cause uneconomic or over - use of irrigation water and extreme climatic change that can give rise to flood and drought disaster. The other serious problem in Jakarta is over - pumping of groundwater without considering discharge capacity that has created intrusion of sea water and groundwater pollution. Since that, Jakarta inhabitants consume more and more mineral water. The cost of mineral water is between Rp.1000 to Rp.1500 per bottle (500 to $600 \mathrm{ml}$ ) compared to the cost of premium (engine fuel) at Rp. 4500/litre. Therefore, selling drinking water has become 'big business' even more profitable than selling engine fuel (premium/benzine). In some areas (for example in mountain regions), private companies monopolize water sources, preventing local inhabitants from continuing to draw water from the source. We must extend drinking water ethics to include both groundwater and water from other sources. The case of Jakarta demonstrates how people living around estuaries also depend on rivers and surface water for their drinking water supply. The last one is weak water user associations that have reduced the effectiveness of irrigation water management at the on - farm level. To illustrate, it is reported that of 39,000 existing or newly - created water user associations, only 11,000 units (28 percent) were in fact developed enough to function properly. Therefore, the demand on water supplies increase by $200 \%$ in the next 15 years (See Table 1), therefore desalination is considered to be the promising method to solve this problem [1,2]

Table 1. Indonesia water potential total water, Surface Water and Ground Water Availability [1,2].

\begin{tabular}{|c|c|c|c|c|c|c|c|}
\hline \multirow[t]{3}{*}{ Island(s) } & Area & Population & Water & \multicolumn{2}{|c|}{ Water Demand } & \multicolumn{2}{|c|}{ Water Resource } \\
\hline & \multirow{2}{*}{$\begin{array}{c}\text { Million- } \\
\mathrm{km}^{2}\end{array}$} & \multirow[t]{2}{*}{ Million } & \multirow[t]{2}{*}{ (mill.m m $\left.^{3} / \mathrm{yr}.\right)$} & \multicolumn{2}{|c|}{ (mill.m³/yr.) } & \multicolumn{2}{|c|}{ (Thousand $\mathrm{m}^{3} / \mathrm{yr}$.) } \\
\hline & & & & 2000 & 2015 & Per-km ${ }^{2}$ & Per-capita \\
\hline Java & 0.133 & 113.6 & 187,000 & 83,378 & 164,672 & 1,406 & 1.6 \\
\hline Lesser Sunda & 0.086 & 10.8 & 60,000 & 13,827 & 42,274 & 698 & 5.5 \\
\hline Celebes & 0.187 & 13.5 & 247,000 & 25,555 & 77,305 & 1,321 & 18.3 \\
\hline Sumatra & 0.471 & 40.1 & 738,000 & 25,298 & 49,583 & 1,567 & 18.4 \\
\hline Borneo & 0.535 & 10.2 & $1,008,000$ & 8,204 & 23,093 & 1,884 & 98.8 \\
\hline Mollucas+Papua & 0.492 & 3.9 & 981,000 & 589 & 1,886 & 1,994 & 251.5 \\
\hline Indonesia & 1.905 & 192.2 & $3,221,000$ & 156,850 & 358,813 & 1,690 & 16.8 \\
\hline
\end{tabular}

In an effort to meet the current and future energy demands, Indonesia initiated and carried out Nuclear Power Plant (NPP) programs in the early 1990s, although they had been suspended following the epidemic economic crisis in Asia on 1997. Nevertheless, other activities, such as IAEA Extra Budgetary Programs, have continued in order to develop the knowledge and operational experiences on the existing three Indonesian research reactors, 
thereby building grass-root knowledge on NPP for future constructions. Indonesia is now planning to utilise nuclear power and the first plant will be built in Muria Area on 2016 (Ujung Lemah Abang, Ujung Watu and Ujung Grenggengan). The introduction of NPP in Indonesia is to reach an optimum energy mix considering cost, environment, and to relieve the pressure arising from increasing domestic demand for oil and gas. The Presidential Decree Number 5 year 2006 on National Energy Policy specified the share of new and renewable energy, especially: biomass, nuclear, hydro, solar and wind in the national energy mix should reach more than 5\% in the year 2025 .

Feasibility and option studies have been carried out by Indonesian National Nuclear Energy Agency, locally called Badan Tenaga Nuklir

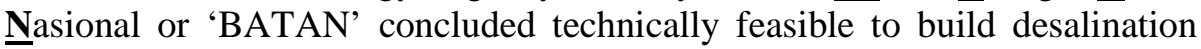
plants on selected sites pending further economic assessments [3]. The other important program is to evaluate the appropriate desalination that would be applied to Muria site. The concept design and basic plant diagram is described somewhere [4].

Presently about $30 \%$ of the world's primary energy is used for electricity production, and approximately $2 / 3$ of this energy is thrown away as waste heat. Therefore, direct use of heat energy is more desirable from an energy efficiency point of view and the optimizing the nuclear heat for both electric and non electric applications are applied. Experience in co-generation of nuclear electricity and heat has been gained in Bulgaria, Canada, China, Hungary, Kazakhstan, Russia, Slovakia and Ukraine.

BATAN also start doing study on both electric and non electric application of nuclear power and will be described in this paper.

\section{TYPE OF NUCLEAR REACTORS}

Various types of reactors are designed with different ranges of inlet and outlet coolant temperatures, and hence will be useful for different applications. Table 2 shows the range of coolant temperatures for different reactor types.

Table 2. Temperature Capabilities of Reactor Types [5].

\begin{tabular}{|l|c|}
\hline \multicolumn{1}{|c|}{ Reactor Type } & $\begin{array}{c}\text { Typical Primary Coolant Inlet } \\
\text { \& Outlet } \\
\text { Temperatures }\left({ }^{\circ} \mathrm{C}\right)\end{array}$ \\
\hline Pressurized Water Reactor (PWR) & $280-320$ \\
\hline Water Reactor (BWR) & $278-288$ \\
\hline Heavy Water Reactor (HWR) & $250-295$ \\
\hline Liquid Metal-cooled Reactor (LMCR) & $390-540$ \\
\hline $\begin{array}{l}\text { High Temperature Gas-cooled Reactor } \\
\text { (HTGR) }\end{array}$ & $500-950$ \\
\hline
\end{tabular}


A nuclear plant can provide steam with temperature start from $100^{\circ} \mathrm{C}$ which can be used for district heating or desalination and $1000^{\circ} \mathrm{C}$ for very high temperature industrial applications. Table 3 shows the characteristic parameters of steam that could be produced by various reactor types. Water reactors can provide steam in the range of 250 to $300^{\circ} \mathrm{C}$ at about 5 to $7 \mathrm{MPa}$ pressure, while liquid metal and gas cooled reactors can generate steam at higher temperature and pressure. LMFBRs can provide steam at approximately $500^{\circ} \mathrm{C}$ and gas cooled reactors at somewhat higher temperatures [5].

Table 3. Typical Steam Production by different Reactor Types [5].

\begin{tabular}{|l|c|c|}
\hline \multirow{2}{*}{ Nuclear Power Plant } & \multicolumn{2}{|c|}{ Steam Parameters } \\
\cline { 2 - 3 } & Pressure $(\mathrm{MPa})$ & Temperature $\left({ }^{\circ} \mathrm{C}\right)$ \\
\hline PWR (U-tube SG) & 6.5 & 280 \\
\hline PWR (Once-through SG) & 6.9 & 312 \\
\hline BWR & 5.5 & 270 \\
\hline PHWR & 5.6 & 271 \\
\hline CANDU PHWR & 4.7 & 260 \\
\hline Phenix LMFBR & 16.3 & 510 \\
\hline THTR-300 & 18.1 & 530 \\
\hline Fort St.Vrain HTGR & 17.3 & 541 \\
\hline
\end{tabular}

From that feature it is known that HTGR is a potential one to be used for non-electric applications. Its heat energy range is possible to be used for hydrogen and methanol productions, enhance oil recovery, coal liquefaction and desalination process.

\section{INDUSTRIAL PROCESS HEAT SUPPLY}

There are five primary areas of industrial heat applications: food processing, paper industry, chemical industry, petroleum and coal processing, and primary metal industries. Industrial process heat is mainly used in the form of steam at appropriate temperature and pressure conditions. The demand is usually steady and there is no seasonal variation and hence quite suitable for supply by nuclear power. The only problem is that the source must be nearby as heat loss in transit is considerable. There are three cases of commercial use of nuclear process heat in Canada, Germany and Switzerland. This is shown in Table 4. The application to the heavy water production facility in Bruce, Canada was the largest use of nuclear process heat and it has operated very successfully for over 20 years. The six other industries the Bruce complex provided process heat were plastic film manufacturing, ethanol plant, apple juice concentration plant, alfalfa 
dehydration, cubing and pelletizing plant, a greenhouse, and an agricultural research facility.

Table 4. Nuclear Plants providing Commercial Process Heat [5].

\begin{tabular}{|c|c|c|c|c|c|c|c|c|}
\hline \multirow[t]{2}{*}{ Country } & \multirow[t]{2}{*}{$\begin{array}{l}\text { Plant } \\
\text { Name }\end{array}$} & \multicolumn{2}{|c|}{$\begin{array}{ll}\text { Start } & \text { of } \\
\text { Operation } & \end{array}$} & \multirow[t]{2}{*}{$\begin{array}{l}\text { Power } \\
\text { MWe }\end{array}$} & \multirow{2}{*}{$\begin{array}{l}\text { Heat } \\
\text { Delivery } \\
\text { MWt }\end{array}$} & \multirow{2}{*}{$\begin{array}{l}\text { Interface } \\
\text { Temp C } \\
\text { Feed/ } \\
\text { Return }\end{array}$} & \multirow{2}{*}{$\begin{array}{l}\text { Distance } \\
\text { to } \\
\text { Industry } \\
\text { Km }\end{array}$} & \multirow[t]{2}{*}{ Application } \\
\hline & & Reactor & Heat & & & & & \\
\hline Switzerland & $\begin{array}{l}\text { Goesgen } \\
\text { PWR }\end{array}$ & 1979 & 1979 & 970 & 25 & $220 / 100$ & 1.75 & $\begin{array}{l}\text { Cardboard } \\
\text { Factory }\end{array}$ \\
\hline Canada $^{\mathrm{a}}$ & $\begin{array}{l}\text { Bruce-A } \\
\text { CANDU }\end{array}$ & $\begin{array}{c}1977- \\
87\end{array}$ & 1981 & $\begin{array}{l}4 \times 848 \\
4 \times 860\end{array}$ & 5350 & & $\begin{array}{l}\text { Nearby } \\
\text { industrial } \\
\text { complex }\end{array}$ & $\begin{array}{l}\text { Heavy } \\
\text { water } \\
\text { production } \\
\text { and } 6 \text { other } \\
\text { industries }\end{array}$ \\
\hline Germany & $\begin{array}{l}\text { Stade } \\
\text { PWR }\end{array}$ & 1983 & & 640 & 30 & $190 / 100$ & 1.5 & $\begin{array}{l}\text { Salt } \\
\text { refinery }\end{array}$ \\
\hline
\end{tabular}

a Unit 2 of Bruce A was taken out of service in 1995, units 1,3 and 4 were taken out of service in 1998. They are expected to start up in 2003.

Table 5. Temperature Needs of Various Types of Industrial Process [5].

\begin{tabular}{|l|l|c|}
\hline No & \multicolumn{1}{|c|}{ Industrial Process } & $\begin{array}{c}\text { Approx. } \\
\text { Temperature Range } \\
\text { (Centigrade) }\end{array}$ \\
\hline 1 & Home and building heating & $100-170$ \\
\hline 2 & Desalination & $100-130$ \\
\hline 3 & Vinyl Chloride production & $100-200$ \\
\hline 4 & Urea synthesis & $180-280$ \\
\hline 5 & Process Steam & $200-400$ \\
\hline 6 & Paper and pulp production & $200-400$ \\
\hline 7 & Oil refining & $200-600$ \\
\hline 8 & Oil shale and oil sand processing & $300-600$ \\
\hline 9 & Crude oil desulphurization & $300-500$ \\
\hline 10 & Petroleum refineries & $450-550$ \\
\hline 11 & $\begin{array}{l}\text { Production of synthetic gas and Hydrogen } \\
\text { from natural gas or naphtha }\end{array}$ & $400-800$ \\
\hline 12 & Steel making via direct reduction & $500-1000$ \\
\hline 13 & Iron industry & $600-1600$ \\
\hline 14 & Production of styrene from ethyl-benzene & $600-800$ \\
\hline 15 & Production of ethylene from naphtha or ethane & $700-900$ \\
\hline 16 & $\begin{array}{l}\text { Hydrogen production by thermo-chemical } \\
\text { reaction }\end{array}$ & $600-1000$ \\
\hline 17 & Coal processing & $400-1000$ \\
\hline 18 & Coal gasification & $800-1000$ \\
\hline
\end{tabular}


The other various industrial processes are shown in Table 5. They vary from low temperature applications for home and building heating to high temperature industrial process of coal gasification. District heating systems from nuclear power plants have been operated reliably in many countries, particularly in Eastern Europe. Fuel synthesis industry also has been coupled with the nuclear power that can generate high temperature heat. Beside that, hydrogen production, coal gasification and production of other fuels also can be coupled with nuclear power plants. There are more than 150 reactor-years of operating experience with nuclear desalination, particularly in Japan and Kazakhstan.

Some important processes will be described below.

\section{Desalination}

Nuclear desalination can be described as production of potable water from seawater or brackish water in a facility in which a nuclear reactor is used as the source of energy for the desalination process.

The possibility of using nuclear energy for desalination of seawater was realized as early as the 1960 s and has evolved over the past 50 years to large-scale commercial processes. The major commercially available processes are of two kinds: (a) thermal processes, where heat is used to vaporize and distill fresh water from saline water; these are multi-stage flash distillation (MSF), multiple-effect distillation (MED), and vapor compression $(\mathrm{VC})$, and (b) membrane processes where suitable membranes are used for the separation of salts such as the mechanism of reverse osmosis (RO). There are also other minor processes such as freezing and solar evaporation. Globally about 26 million $\mathrm{m}^{3} / \mathrm{d}$ of fresh water is produced by desalination (including both brackish and seawater plants). The maximum is produced in Saudi Arabia, about 21\%. The U.S. produces approximately 17\%, $80 \%$ of which is achieved by membrane processes.

Experience with nuclear desalination now exceeds 150 reactor-years. Table 6 gives a list of the nuclear plants, which have been used for desalination of water; it also provides information about the reactor types, desalination technologies employed and the fresh water capacity of the plant. It should particularly be noted that there was no incidence of radioactive contamination of the water produced. 
Table 6. Experience in Nuclear Desalination Plants [5].

\begin{tabular}{|l|c|c|c|c|}
\hline Plant Name & $\begin{array}{c}\text { Reactor } \\
\text { Type }\end{array}$ & $\begin{array}{c}\text { Gross } \\
\text { Power } \\
\text { (MWe) }\end{array}$ & $\begin{array}{c}\text { Desalination } \\
\text { Process }\end{array}$ & $\begin{array}{c}\text { Water } \\
\text { Capacity } \\
\mathrm{M}^{3} / \mathrm{d}\end{array}$ \\
\hline Ikata-1,2 (Japan) & PWR & $2 \times 566$ & MSF & 200 \\
\hline Ikata-3 (Japan) & PWR & 890 & RO & 2,000 \\
\hline Ohi-1,2 (Japan) & PWR & $2 \times 1175$ & MSF & 3,900 \\
\hline Ohi-3,4 (Japan) & PWR & $2 \times 1180$ & RO & 2,600 \\
\hline Genkai-4 (Japan) & PWR & 1180 & RO & 1,000 \\
\hline $\begin{array}{l}\text { Genkai-3,4 } \\
\text { (Japan) }\end{array}$ & PWR & $2 \times 1180$ & MED & 1,000 \\
\hline $\begin{array}{l}\text { Takahama-3,4 } \\
\text { (Japan) }\end{array}$ & PWR & $2 \times 870$ & MED & 1,000 \\
\hline $\begin{array}{l}\text { Kashiwazaki } \\
\text { (Japan) }\end{array}$ & BWR & 1100 & MSF & 1,000 \\
\hline $\begin{array}{l}\text { KANUPP } \\
\text { (Pakistan) }\end{array}$ & PHWR & 137 & RO & 454 \\
\hline $\begin{array}{l}\text { BN-350 } \\
\text { (Kazakhstan) }\end{array}$ & $\begin{array}{l}\text { LMR 150 } \\
\text { (till 1999) }\end{array}$ & $\begin{array}{c}150 \\
\text { (till 1999) }\end{array}$ & MSF \& MED & $\begin{array}{c}80,000 \\
\text { (potable) }\end{array}$ \\
\hline
\end{tabular}

The desalination costs range from $\$ 0.40$ to $\$ 1.90$ per $\mathrm{m}^{3}$ of fresh water produced. From current exist nuclear desalination, it was generally found that (a) MSF processes cost higher than RO and MED processes, (b) RO and MED processes costs are in general comparable, (c) RO is economically more favorable for less stringent drinking standards, and (d) desalination costs are higher for smaller reactors.

Nuclear desalination is a matured technology that can be installed in many nuclear plants to provide fresh water to solve regional water shortage problems and various research and construction project studies are still being performed in several countries. The desalination capacities in the world increase double each decade and many efforts are now primarily directed towards reducing production cost of desalinated water through innovations and technological enhancements.

Table 7. Nuclear Desalination Operating Experience [5].

\begin{tabular}{|l|c|c|c|}
\hline & Japan & Kazakhstan & Pakistan \\
\hline Starting Year & 1978 & 1973 & 2000 \\
\hline Reactor Type & LWR & LMR & PHWR \\
\hline $\begin{array}{l}\text { Capacity } \\
\left(\mathrm{m}^{3} / \text { day) }\right.\end{array}$ & $100-3900$ & $\begin{array}{c}80,000 \\
\text { (design } 120,000)\end{array}$ & 454 \\
\hline Average salinity & 35,000 & 13,500 & 24,000 \\
\hline
\end{tabular}




\begin{tabular}{|c|c|c|c|}
\hline $\begin{array}{l}\text { of intake water } \\
(\mathrm{mg} / \mathrm{l})\end{array}$ & & & \\
\hline $\begin{array}{l}\text { Average } \\
\text { temperature }\left({ }^{\circ} \mathrm{C}\right)\end{array}$ & 17 & 2 & 24 \\
\hline Radioactive leak & None & None & None \\
\hline $\begin{array}{ll}\text { Water } & \\
\text { Production } & \\
\text { during } & \text { NPP } \\
\text { shutdown } & \end{array}$ & $\begin{array}{l}\text { Water Production } \\
\text { during NPP } \\
\text { shutdown Halted, no } \\
\text { need for water. No } \\
\text { backup source }\end{array}$ & $\begin{array}{l}\text { Continued by a } \\
\text { fossil boiler }\end{array}$ & None \\
\hline $\begin{array}{l}\text { Failures and } \\
\text { types }\end{array}$ & Nothing reported & $\begin{array}{l}\text { Corrosion and } \\
\text { erosion of tubes and } \\
\text { pump blades }\end{array}$ & $\begin{array}{c}\text { Not } \\
\text { reported }\end{array}$ \\
\hline Availability & $\begin{array}{l}\qquad \sim 50 \% \\
\text { Not operated once } \\
\text { the storage tank is } \\
\text { filled. }\end{array}$ & $85 \%$ & \\
\hline $\begin{array}{l}\text { Product water } \\
\text { use }\end{array}$ & $\begin{array}{l}\text { In plant use for } \\
\text { steam cycle }\end{array}$ & $\begin{array}{l}\text { In plant } \quad \& \\
\text { municipal } \\
\text { including } \\
\text { water }\end{array}$ & $\begin{array}{c}\text { In plant } \\
\text { use }\end{array}$ \\
\hline
\end{tabular}

\section{Coal gasification}

Coal gasification is a process conversion of solid coal into a gaseous fuel like the natural gas. It requires very high temperatures.

The efficiency of coal fire plants will also be improved by coal gasification because it can remove environmental pollutants such as particulates like sulfur-dioxide and nitrogen oxides. The process is quite energy intensive; one unit of gasified coal may require about 1.7 units of energy in solid coal. High temperature gas-cooled reactors can play a role here.

\section{Coal Liquefaction}

The coal liquefaction is a process conversion of solid coal into liquid. The process can be divided into two processes, i.e. direct and indirect. (1) Direct process is the process of decomposing high molecular structural of coal into lower structural of artificial petroleum with catalyst in a hydrogen donor solvent at very high temperature and pressure. Direct coal liquefaction is considered to take place into two consecutive steps: conversion to a soluble form (dissolution or depolymerization) and reduction in molecular weight and removal of heteroatom, which is often called as upgrading process. (2) Indirect process is the production of hydrocarbons from carbon monoxide 
and hydrogen in the presence of Fischer-Tropsch catalyst. The process itself is defined by adjusting the composition of catalyst, hydrogen/carbon ratio and operating conditions, therefore variety of products can be obtained. Moreover, the other products such as methanol and acetone can also be produced by using different catalyst.

Coal liquefaction can be one possible solution for future energy in Indonesia, particularly in the transportation sector; the $\mathrm{R} \& \mathrm{D}$ is being carried out by BPPT.

\section{Fuel Synthesis}

Gas-cooled reactors can generate very high temperatures, which could be used to create new synthetic fuels for energy. This will be an innovative application of nuclear energy and can considerably expand its use. This is because the transportation sector is responsible for about a quarter of the total energy use and almost $99 \%$ of this is currently supplied by organic fuel. Nuclear power can penetrate this large market through use of electric cars and production of synthetic fuels such as methanol, ethanol and their derivatives; nuclear power can also be used for coal gasification, oil extraction and hydrogen production. All of these are being seriously considered in the 21st century. However, the infrastructure for use of these fuels needs to be created first, particularly in the case of environmentally ideal hydrogen fuel.

The feasibility of nuclear application for production of more organic fuel really depends on the economics. So long as fossil fuel, particularly oil and gas, are available at low prices, nuclear will not be a preferable option. Only dual use, where nuclear electricity can compete in the market, could make these applications worthwhile.

Hydrogen is one of the energy that can be storage able, transportable, can be used in transport systems, home, industry, and the most important one is a clean and inexhaustible energy. Therefore, hydrogen is named by "clean energy" or environmentally clean and renewable energy source on large scale. Hydrogen is considered to be the one that can replace all the positions of fossil fuels. The most interesting one is the raw material this process is water which relatively clean, a hundred per cent free carbon element. Hydrogen is used in the chemical industry for producing ammonia, plastic, foodstuffs, rubber and pharmaceuticals and also as a reducing agent in the metallurgical and scrap-metal recovery industry.

There are many methods for producing hydrogen such as by thermolysis, thermo chemical cycle, electrolysis, photolysis and bioproduction by using bacteria. However, electrolysis and thermo chemical cycle are the promising one and has a good prospect in the future.

Hydrogen economy has received renewed interest because of new developments in HTGR technologies. Several paths to hydrogen production 
are being considered: decomposition and gasification of fossil fuel such as steam reforming of methane and carbon dioxide reforming of methane; and decomposition of water, namely, low-temperature electrolysis, and combination of electricity and heat for high temperature electrolysis. These are briefly described below.

\section{Steam Reforming of Methane}

In this method Methane $\left(\mathrm{CH}_{4}\right)$, a main component of natural gas and water react at temperatures of $600-800^{\circ} \mathrm{C}$ to produce hydrogen and carbon monoxide and dioxide. The steam reforming system can be easily coupled to a HTGR, which can provide the necessary heat and high temperature. Considerable R\&D work has been carried out in Germany for the steam reforming of methane including performing experiments in a pilot plant, EVA-I and EVA-II. Currently work is in progress in JAEA for the HTTR, in China for the HTR-1015 and in Russia.

\section{$\mathrm{CO}_{2}$ Reforming of Methane}

The basic $\mathrm{CH}_{4}$ and $\mathrm{CO}_{2}$ reaction for this process (with no addition of steam) produces $\mathrm{CO}$ and hydrogen. The reforming process requires high temperature $\left(800-900^{\circ} \mathrm{C}\right)$ and high energy input, both of which can be provided by HTGRs. The Desalination \& Other generated $\mathrm{CO}$ and $\mathrm{H}_{2}$ mixture (syngas) can be used directly as fuel for electricity generation (e.g., by fuel cells).

\section{Electrolysis process}

Water electrolysis at ambient pressure and temperature of $70-90^{\circ} \mathrm{C}$ is a common method for production of high purity hydrogen. However, it has been found that the demand for electricity decreases with increase of temperature. That is the electric energy required is much reduced for the electrolysis of steam at higher temperatures $\left(800^{\circ} \mathrm{C}\right.$ and above). High temperature electrolysis is a reverse reaction of the Solid-oxide Fuel Cell, where water is decomposed in the solid polymer electrolyte to hydrogen and oxygen. This method is at an early stage of development.

About $1 \%$ of worldwide hydrogen demand is produced by this process, but the cost is more expensive than that fossil fuels. JAEA is developing the ceramic cell for this purpose. 


\section{Thermo chemical cycle}

This is a process that having operated temperature lowers than $1000^{\circ} \mathrm{C}$. There are thousands of thermo chemical cycle have been proposed in USA, Europe and Asia, but only few per cent of those cycles are continuously studied to bench-scale and pilot plant. Among these cycles, the Sulfur family (Iodine Sulfur (IS) cycle and Mark cycle) and bromine family (University of Tokyo (UT)-3 cycles) are the promising one.

One mechanism that is being considered seriously for hydrogen production is thermo-chemical water splitting by the Iodine-Sulfur (IS) process. The IS process was originally proposed by the General Atomic Company in early 1970's and is very promising because it involves only a few reaction steps. In this process Hydrogen- Iodide (HI) is produced by a cyclic chemical reaction chain utilizing Iodine, sulfur dioxide and water; HI is then decomposed to produce hydrogen, releasing Iodine to the chemical reaction chain. Sulfuric acid, $\mathrm{H}_{2} \mathrm{SO}_{4}$, is generated in the process, which is vaporized and decomposed at a temperature of about 800 to $900^{\circ} \mathrm{C}$ to sulfur dioxide, water and oxygen. The oxygen is released and sulfur-dioxide and water is returned to the reaction cycle. Laboratory scale experiments at Japan Atomic Energy Research Institute have demonstrated the feasibility of the IS process with continuous generation of hydrogen from water with recycling of the process material. An energy efficiency of $47 \%$ has been achieved in this process.

The IS cycle consist of 3 steps of reactions as follow

$$
\begin{aligned}
& \mathrm{I}_{2}+\mathrm{SO}_{2}+2 \mathrm{H}_{2} \mathrm{O}=\mathrm{H}_{2} \mathrm{SO}_{4}+2 \mathrm{HI} \\
& 2 \mathrm{HI} \quad \mathrm{H}_{2}+\mathrm{H}_{2} \\
& \mathrm{H}_{2} \mathrm{SO}_{4} \quad=\mathrm{H}_{2} \mathrm{O} \quad+\mathrm{SO}_{2}+0.5 \mathrm{O}_{2}
\end{aligned}
$$

The UT-3 cycle consist of 4 steps of reactions as follow:

$\begin{array}{llll}\mathrm{CaBr}_{2} & +\mathrm{H}_{2} \mathrm{O} & =\mathrm{CaO} & +2 \mathrm{HBr} \\ \mathrm{CaO} & +\mathrm{Br}_{2} & =\mathrm{CaBr}_{2}+0.5 \mathrm{O}_{2} & \\ \mathrm{Fe}_{3} \mathrm{O}_{4}+8 \mathrm{HBr} & =3 \mathrm{FeBr}_{2} & +4 \mathrm{H} 2 \mathrm{O}+\mathrm{Br}_{2} \\ 3 \mathrm{FeBr}_{2}+4 \mathrm{H}_{2} \mathrm{O} & =\mathrm{Fe}_{3} \mathrm{O} 4+\mathrm{H}_{2}\end{array}$

The present hydrogen production plant in Indonesia is in Balik Papan and Dumai with production capacity of 68,000 and 79,000 MMSFC.(Lemigas, 1994) One of the activity that BATAN doing now is the basic research on separation product hydrogen with Iodium gas. This research is supported by the government under incentive program now. 


\section{BATAN ACTIVITIES}

From the explanation above, it is understood that HTGR is the promising future type of NPP that can be coupled with various type of industrial process which need heat as an energy source, to enhance the its heat efficiency. BATAN starts to study the non electric application of nuclear power plant from more than 10 years ago. The chosen nuclear power plant for that purpose is also HTGR. Many theoretical and literature studies have been done. At present, the type of technological study that has been doing by BATAN is desalination and hydrogen production.

The present status for desalination study is the development of a small scale Mechanical Vapor Compression (MVC).

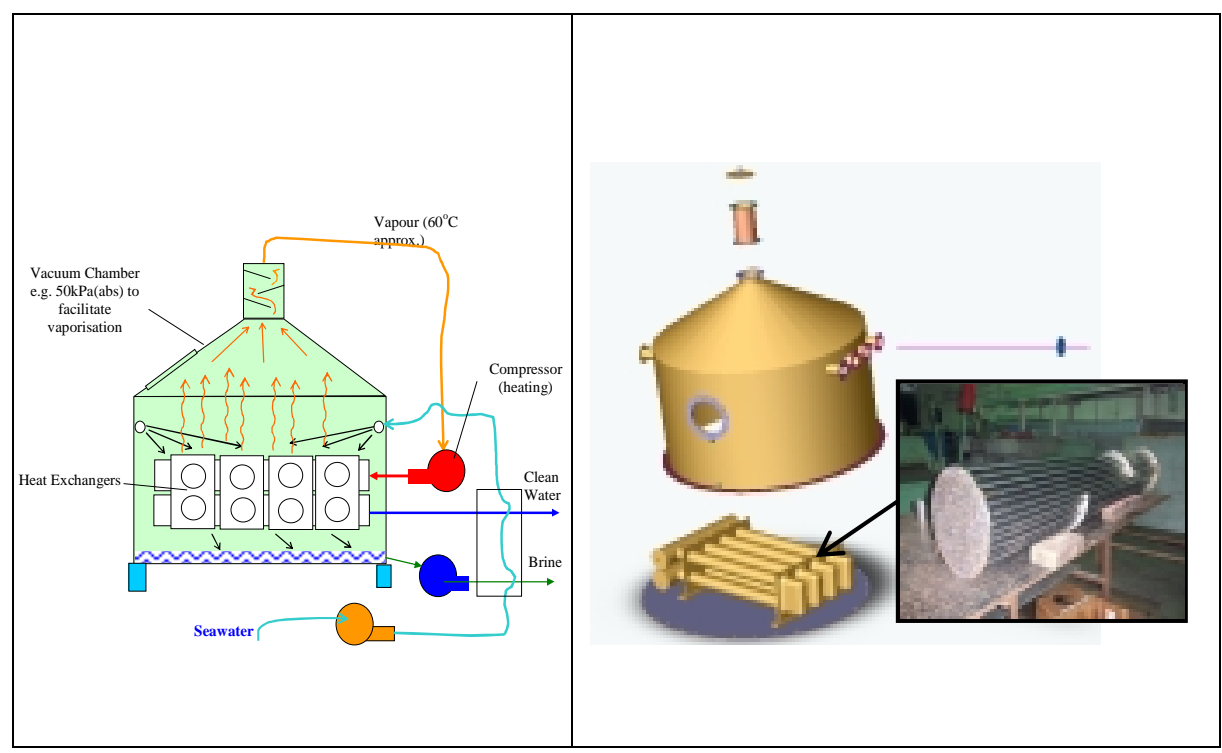

Figure 1. Simplified Concept Diagram (a) and prototype Model (b).

A small scale MVC is shown in Figure 1. The production rate of water is $0.5 \mathrm{~m}^{3} /$ day. Power consumption is estimated to be $322 \mathrm{kWh} / \mathrm{m}^{3}$. Desalination efficiencies have been studied in terms of heat exchanger capacities and fresh water production rates. See Figure 1. The capacity of the main heat exchanger is found to be dominating the system performance and directly affects the product throughput. That is, any increase in heat exchanger size is realized by a greater gain in fresh water production. Increase in brine preheater size also shows great return up to a certain desalination throughput, $0.1 \mathrm{~kg} / \mathrm{s}$, after which, the net gain is significantly retarded although continues to increase. On the other hand, little performance gain is observed when the fresh water preheater capacity is increased. This is yet to be tested to validate the design upon completion of system 
construction. Effects of demister densities also have been studied. Although it did not change flow patterns, power consumption increased from 300 to $500 \mathrm{kWh} / \mathrm{m}^{3}$ as the demister density was changed from 200 to $930 \mathrm{~kg} / \mathrm{m}^{3}$.

The present status for hydrogen production is a basic study on IodineSulfur Thermochemical process to enhance the process efficiency.

\section{CONCLUSION}

HTGR is the promising future type of nuclear reactor for Indonesia because it has very high outlet temperature from the primary cooling $\left(950^{\circ} \mathrm{C}\right)$ that can be utilized for various industrial processes. The purpose of multi used heat is to enhance the heat efficiency. The probable industries that have been studying at present for its coupling are coal liquefaction, hydrogen production and desalination. These industries need a proper temperature and pressure, therefore to prevent the heat loss in transit, the probable industries are considered better to be built nearby the NPP.

\section{REFERENCE}

1. MACHBUB, Pengelolaan Sumberdaya Air Berwawasan Lingkungan pada Pengembangan Wilayah.

2. PANGESTI, Pengelolaan dan Pemanfaatan Sungai Menyongsong Abad 21 (2000).

3. S. H. KIM et. al, International Journal, Nuclear Desalination, Volume 1, No. 4 (2005).

4. GENI RINA SUNARYO and PURADWI ISMU WAHYONO, 'Prospect on Desalination by Nuclear Energy in Indonesia', Conference on NonElectric Applications of Nuclear Power: Seawater Desalination, Hydrogen Production and other Industrial Applications', held in Oarai, Japan, April 16-19, (2007).

5. DEBU MAJUMDAR, 'Desalination and other Non-Electric Application of Nuclear Energy', Workshop on Nuclear Reaction Data and Nuclear Reactors Physics, Design and Safety, Trieste, February 25 March 28, (2002). 